\title{
Effect of hesperidin addition to quail diets on fattening performance and quality parameters, microbial load, lipid peroxidation and fatty acid profile of meat
}

\author{
A. Özbilgin ${ }^{1}, \mathrm{~K} . \mathrm{Kara}^{2,4}$ and S. Urçar Gelen ${ }^{3}$ \\ ${ }^{1}$ Sivas Cumhuriyet University, Faculty of Veterinary Medicine, Department of Animal Nutrition and Nutritional Diseases, \\ 58140, Sivas, Turkey \\ ${ }^{2}$ Erciyes University, Faculty of Veterinary Medicine, Department of Animal Nutrition and Nutritional Diseases, \\ 38280, Kayseri, Turkey \\ ${ }^{3}$ Atatürk University, Faculty of Veterinary Medicine, Department of Food Hygiene and Technology, 25240, Erzurum, Turkey
}

KEY WORDS: fatty acids, hesperidin, lipid peroxidation, meat quality, microbial count, quails

Received: 21 May 2021

Revised: 17 August 2021

Accepted: 15 October 2021

\begin{abstract}
This study examines the effect of different doses of hesperidin added to quail diets on growth performance of birds as well as on lipid peroxidation, some microbiological and physicochemical properties, and fatty acid profile of thigh tissue. In total 300 (male and female) Japanese quail (Coturnix coturnix japonica) were divided into three groups: control (C) group fed only a basal diet, HES1 and HES2 groups fed basal diet with the addition of 1 and $2 \mathrm{~g} / \mathrm{kg}$ hesperidin, respectively. It was observed that hesperidin addition to quail diets had no effect on the growth performance parameters, such as live weight, feed consumption and feed conversion ratio, regardless of examined dose. It was determined that hesperidin dose did not affect meat water activity $(P>0.05)$ but influenced $\mathrm{pH}$ or colour parameters [brightness $\left(L^{*}\right)$, redness $\left(a^{*}\right)$, yellowness $\left.\left(b^{*}\right)\right]$ of meat $(P<0.05)$. Furthermore, the antibacterial effect of hesperidin supplementation was observed as counts of total mesophilic bacteria, Enterobacteriaceae, Lactobacillus spp., Lactococcus spp., Micrococcus/Staphylococcus and total psychrophilic aerobic bacteria were limited and variable $(P<0.05)$. It was determined that hesperidin had a statistically significant effect on lipid peroxidation in meat on day 1 and 4 of storage. In addition, it was observed that the added hesperidin had a positive effect on n-3 polyunsaturated fatty acids (PUFA; such as a-linolenic acid, eicosapentaenoic acid and docosahexaenoic acid) in terms of the lipid profile in thigh tissue $(P<0.05)$. So, it can be concluded that the hesperidin addition to quail diets exerted influence on microbiological properties and lipid peroxidation of meat, which can influence shelf life quality of quail meat; but also hesperidin addition had a health-promoting effect on the fatty acid profile of thigh meat increasing n-3 PUFA content.
\end{abstract}

${ }^{4}$ Corresponding author: e-mail: karakanber@hotmail.com deterioration of the colour, smell and taste of meat due to oxidation processes (Engberg et al., 1996). Cells are susceptible to oxidation due to the properties of membrane phospholipids and their high content of unsaturated fatty acids, which leads to the formation of secondary products of oxidation fatty acid contents (Simopoulos, 2000). However, a high unsaturation of fatty acid in tissue can lead to

\section{Introduction} Poultry meat has many desirable nutritional
properties due to its low-fat and high-unsaturated 
reactions, such as short-chain aldehydes, ketones or hydroperoxides. These compounds can adversely affect lipids, pigments, proteins, carbohydrates and vitamins, and consequently, result in the loss of important features, such as the meat flavour, colour, nutritional value and quality, which limits the shelf life of the product (Maraschiello et al., 1998; Sárraga and García-Regueiro, 1999). Flavonoids usually contain one or more aromatic hydroxyl groups that reduce free radicals and are responsible for antioxidant activity. They are commonly found in plant products as secondary metabolites, synthesized for defense against ultraviolet light, physical damage, stress, pathogens and infections (Robbins, 2003). Flavonoids, and especially the subgroup of flavanones containing hesperidin and naringin that are well known for their antioxidant properties, have multifactorial activities and are compounds that assure health to living organisms (Erlund, 2004).

Green tea, rosemary and grape pulp, which are rich in phenolic substances with antioxidant activity, have been added to poultry rations as raw materials and extracts (Smet et al., 2008; Kara et al., 2016a,b,c; 2021). In recent years, there have been more and more attempts to add by-products, especially from citrus fruits, to animal diets. Citrus pulp is obtained after removing the juice from the fruit and is therefore a mixture of citrus peels, their insides, and part of the peel. Citrus pulp and residues are widely used in animal feeding. They have a positive impact on expensive waste management programmes prevention. Fibres obtained from citrus fruit pulp have an additional advantage: they contain bioactive compounds (flavonoids) - functional components providing health benefits as mentioned above. Bioflavonoids such as hesperidin and naringenin are abundant as an inexpensive by-product of citrus cultivation.

Hesperidin is a naturally occurring polyphenolic compound widely distributed in the plant kingdom as a secondary metabolite. Hesperidin is a flavanone glycoside comprising an aglycone, hesperitin or methyl eriodictyol and an attached disaccharide, rutinose (Garg et al., 2001). Pure hesperidin occurs as long hair-like needles, yellow in colour. It is tasteless and odourless. A deficiency of this substance in human diet has been linked with abnormal capillary leakage as well as pain in the extremities causing aches, weakness and leg cramps (Garg et al., 2001).

There are many studies on adding flavonoids extracted from citrus fruits to poultry diets and its effect on live weight changes (Simitzis et al., 2011; Hajati et al., 2012; Goliomytis et al., 2014, 2015). The addition of Gingko biloba extract in varying doses has been also tested (Cao et al., 2012). It was found that hesperidin, which is added to the diet at varying rates, changes the $\mathrm{pH}$ of the meat, also of quail meat (Nasr et al., 2017). Also it was reported that addition of hesperidin to the diet reduces the malondialdehyde (MDA) - lipid peroxidation indicator - concentration in meat (examined hesperidin doses: $1.5-3 \mathrm{~g} / \mathrm{kg}$; Simitzis et al., 2011; Kamboh and Zhu, 2013). The possible positive effects of adding hesperidin to the diet in terms of meat microbial load have been determined until now only in in vitro studies (Karayıldırım, 2017; Ambrosio et al., 2020).

Therefore the aim of the present study was to determine how different doses of hesperidin addition to the quails diets will affect fattening performance of birds, meat quality parameters (microbiological and physicochemical properties (colour) and fatty acid profile) as well as lipid oxidation in meat depending on the storage period.

\section{Material and methods}

\section{Animals, experiment schedule and diets}

This study was conducted with the permission of the Sivas Cumhuriyet University, Animal Experiments Local Ethics Board, dated 2019 and numbered 253 .

In the study, 300 quails (Coturnix coturnix japonica) of mixed sex, aging 10-15 days were housed in cages (20 quails per cage) with dimensions of $20 \times 45 \times 100 \mathrm{~cm}$ in a closed area at the Sivas Cumhuriyet University, Faculty of Veterinary Medicine for a one-week adaptation period and then 5 weeks of experimental period. Animals were distributed without causing a statistical difference between the control and trial groups in terms of average live weight values. In the experiment, the birds were divided into 3 groups of 100 birds each, and each group was divided into 5 repetition, 20 quails each. The groups were: control (C) fed only basal diet; HES 1 group fed the basal diet $+1 \mathrm{~g} / \mathrm{kg}$ of hesperidin; HES2 group fed the basal diet $+2 \mathrm{~g} / \mathrm{kg}$ of hesperidin. Hesperidin $\left(\mathrm{C}_{28} \mathrm{H}_{34} \mathrm{O}_{15}\right.$, cas no: 520-26-13, purity grade $91 \%$, Chem-Impex Int. Company, Wood Dale, IL, USA) was obtained from the market as purified from orange fruit. Doses were formulated according to Goliomytis et al. (2015). In the study, animals had ad libitum access to feed and water. All animals experienced a comfortable temperature $\left(22-24^{\circ} \mathrm{C}\right)$ and 23/1 h daylight/darkness per day. Animal diets were formulated according to the recommendations of the National Research Council (NRC, 1994) and the chemical analysis of diets was performed according to the AOAC Internationl (2000) (Table 1). 
Table 1. Composition of basal and experimental diets

\begin{tabular}{|c|c|c|c|}
\hline \multirow{2}{*}{ Indices } & \multicolumn{3}{|l|}{ Diet $^{1}$} \\
\hline & $\mathrm{C}$ & HES1 & HES2 \\
\hline \multicolumn{4}{|l|}{ Feed raw materials, $\%$} \\
\hline maize & 28.83 & 28.83 & 28.83 \\
\hline wheat & 20.24 & 20.24 & 20.24 \\
\hline barley & 4.96 & 4.96 & 4.96 \\
\hline soybean meal, $48 \% \mathrm{CP}$ & 33.35 & 33.35 & 33.35 \\
\hline sunflower meal, $28 \% \mathrm{CP}$ & 10.00 & 10.00 & 10.00 \\
\hline limestone $^{2}$ & 1.37 & 1.36 & 1.35 \\
\hline dicalcium phosphate & 0.65 & 0.65 & 0.65 \\
\hline vitamin-mineral mix ${ }^{3}$ & 0.25 & 0.25 & 0.25 \\
\hline salt & 0.24 & 0.24 & 0.24 \\
\hline L-lysine, hydrochloride & 0.12 & 0.12 & 0.12 \\
\hline hesperidin ${ }^{4}$ & 0 & 0.1 & 0.2 \\
\hline \multicolumn{4}{|l|}{ Nutrient content, calculated } \\
\hline dry matter, $\%$ & 90 & 90 & 90 \\
\hline crude protein (CP), \% & 23 & 23 & 23 \\
\hline metabolic energy, $\mathrm{kcal} / \mathrm{kg}$ & 3000 & 3000 & 3000 \\
\hline calcium, $\%$ & 0.80 & 0.80 & 0.80 \\
\hline usable phosphorus, $\%$ & 0.30 & 0.30 & 0.30 \\
\hline
\end{tabular}

${ }^{1}$ Diets: $\mathrm{C}$ - basal diet, HES1 - basal diet with $1 \mathrm{~g} / \mathrm{kg}$ hesperidin, HES2 - basal diet with $2 \mathrm{~g} / \mathrm{kg}$ hesperidin; ${ }^{2}$ hesperidin replaced limestone in the same amount in the groups with hesperidin addition; ${ }^{3}$ contained per kg: mg: retinol (vitamin A) 3, tocopherol (vitamin E) 30 , menadione (vitamin $\mathrm{K}_{3}$ ) 5 , thiamine (vitamin $\mathrm{B}_{1}$ ) 1, riboflavin (vita$\min B_{2}$ ) 5 , pyridoxin (vitamin $B_{6}$ ) 3 , nicotinic acid 30 , pantothenic acid 10, folic acid 0.8 , ascorbic acid (vitamin C) 10, choline chloride 450, Co 0.2, I 0.5, Se 0.3, Fe 25, Mn 120, Cu 10, Zn 100; $\mu$ g: cholecalciferol (vitamin $\mathrm{D}_{3}$ ) 62.5, cobalamin (vitamin $\mathrm{B}_{12}$ ) 20 , biotin $100 ;{ }^{4}$ molecule formula: $\left(\mathrm{C}_{28} \mathrm{H}_{34} \mathrm{O}_{15}\right)$, cas no: $520-26-13$, purity grade $91 \%$ (Chem-Impex, Wood Dale, IL, USA)

\section{Determining the performance values}

The birds were weighed at the beginning of the experiment and the beginning of fattening was determined by live weight. Then, the birds and the feeds were weighed on days 7, 14, 21, 28 and 35. At the end of the experiment, each repetition was weighed and divided by number of birds to obtain the repetition average than the obtained values were used to calculate the group average final live weight. At the end of the experiment, total feed consumption was calculated after subtracting the given feeds from the remaining feeds. The feed conversion ratio (FCR) was calculated by dividing total feed consumed throughout the experiment by the difference between the final and initial live weights (weight gain). At the end of the experiment, 20 quails (12 for meat quality and 8 for fatty acid analysis) from each group were slaughted and the carcass weight was calculated after removing the feathers, legs and internal organs postslaughter. Carcass yield was calculated by dividing the post-slaughter carcass weight by the final live weight.

\section{Quality characteristics of the meat}

Twenty five-gram samples of the thigh meat taken from slaughtered birds was covered with stretch wrap on polyethylene plates and kept at $4 \pm 1{ }^{\circ} \mathrm{C}$ for further analysis (11 days). The water activity $\left(\mathrm{a}_{\mathrm{w}}\right)$, $\mathrm{pH}$ value and colour parameters $\left(\mathrm{L}^{*}, \mathrm{a}^{*}, \mathrm{~b}^{*}\right)$ of the samples were determined on days $1,4,7$ and 11 . The water activity $\left(\mathrm{a}_{\mathrm{w}}\right)$ value was determined by an Aqualab 4TE device (METER Group, Inc., Pullman, WA, USA). A small amount of meat was placed in the container of the device and the $\mathrm{a}_{\mathrm{w}}$ value was obtained. The $\mathrm{pH}$ values of the samples were obtained according to the method reported by Gökalp et al. (2001). Accordingly, $10 \mathrm{~g}$ of homogenized samples was weighed in parallel and $100 \mathrm{ml}$ of pure water was added. After homogenizing with an Ultra-Turrax device (T25, IKA Werk, Staufen, Germany) for $1 \mathrm{~min}, \mathrm{pH}$ values were determined using a $\mathrm{pH}$-meter (WTW Inolab, Weilheim, Germany). The sectional surface colour densities of the samples $\left(L^{*}, a^{*}, b^{*}\right)$ were determined using a Minolta colorimeter device (CR-200, Minolta Co, Osaka, Japan).

\section{Lipid peroxidation analysis}

In order to carry out the thiobarbituric acid reactive substances (TBARS) assay, in which malondialdehyde (MDA) present in the sample is measured, the homogeneous samples of meat (about $2 \mathrm{~g}$ ) were homogenized with $12 \mathrm{ml}$ of trichloroacetic acid (TCA) solution (7.5\% TCA, 0.1\% EDTA, $0.1 \%$ propyl gallate (dissolved in $3 \mathrm{ml}$ of ethanol)) for 15-20 s in an Ultra-Turrax device (T25, IKA Werk, Staufen, Germany) and then filtered through Whatman 1 filter paper. Filtrate $(3 \mathrm{ml})$ was transferred to the test tube, and $3 \mathrm{ml}$ of thiobarbituric acid (TBA) $(0.02 \mathrm{M})$ solution was added and then it was homogenized again. Next, the test tubes were kept in a water bath for $40 \mathrm{~min}$ at $100{ }^{\circ} \mathrm{C}$ and then cooled in cold water for $5 \mathrm{~min}$. After centrifugation ( $5 \mathrm{~min}$ at $2000 \mathrm{~g}$ ), the absorbance values of the obtained liquid phase were obtained with use of a spectrophotometer (AquaMate 7000 Vis Spectrophotometer, Thermo Fisher Scientific, Waltham, MA, USA) at $530 \mathrm{~nm}$.

\section{Microbial analysis}

Microbiological analysis of the samples was performed according to the proposed method by Baumgart et al. (2015). Samples (25 g) of thigh meat were homogenized in $225 \mathrm{ml}$ of sterilized Ringer solution. Then, the dilutions in Ringer solutions were prepared. The pouring method was used in the inoculations for all bacteria. The total number of mesophilic aerobic bacteria (TMAB) was determined 
on Plate Count Agar (PCA, Merck, Darmstadt, Germany) medium. The petri dishes were incubated aerobically at $30 \pm 1{ }^{\circ} \mathrm{C}$ for $72 \pm 1 \mathrm{~h}$. The total number of psychotrophilic aerobic bacteria (TPAB) was determined on PCA medium. The petri dishes were incubated aerobically at $7 \pm 1{ }^{\circ} \mathrm{C}$ for 10 days. The inoculation was performed by transferring $1 \mathrm{ml}$ from the suitable dilutions with coliform counts into VRBA (Violet Red Bile Agar, Merck, Darmstadt, Germany) medium. Petri plates were incubated in anaerobic conditions for 2 days at $30{ }^{\circ} \mathrm{C}$. The $\mathrm{Mi}$ crococcus/Staphylococcus count was determined on Mannitol Salt Agar (MSA, Merck, Darmstadt, Germany) medium. The petri dishes were incubated aerobically at $30 \pm 1^{\circ} \mathrm{C}$ for $48 \pm 1 \mathrm{~h}$. The Lactobacillus spp. count was determined on MRS (de Man, Rogosa and Sharpe) Agar Base (Merck, Darmstadt, Germany) medium. The petri dishes were incubated anaerobically at $37 \pm 1{ }^{\circ} \mathrm{C}$ for $72 \pm 1 \mathrm{~h}$. The Lactococcus spp. count was determined on M17 Agar Base (Merck, Darmstadt, Germany) medium. The petri dishes were incubated aerobically at $37 \pm 1{ }^{\circ} \mathrm{C}$ for $38 \pm 1 \mathrm{~h}$. The obtained bacterial numbers were expressed as $\log \mathrm{CFU} / \mathrm{g}$.

\section{Fatty acid analysis}

The meat samples were homogenized with tissue grinder (Homogenizer HS-30E, witeg Labortechnik $\mathrm{GmbH}$, Wertheim, Germany) using a pestle with polytetrafluoroethylene head (5553855 number, witeg Labortechnik GmbH, Wertheim, Germany). The grinded sample was mixed with $0.7 \mathrm{ml}$ of potassium hydroxide $(10 \mathrm{M})$ and $5.3 \mathrm{ml}$ of methanol and then it was incubated at $55{ }^{\circ} \mathrm{C}$ for $45 \mathrm{~min}$ in an incubator (Nüve FN 120, Ankara, Turkey). The $0.58 \mathrm{ml}$ of $\mathrm{H}_{2} \mathrm{SO}_{4}(10 \mathrm{M})$ was added to the mixture, vortexed and incubated at $55^{\circ} \mathrm{C}$ for $45 \mathrm{~min}$ again. Then $3 \mathrm{ml}$ of $n$-hexane was added to the mixture and the tubes were centrifuged at $1600 \mathrm{~g}$ for $5 \mathrm{~min}$ (Nüve, Ankara, Turkey) (Wang et al., 2015). After centrifugation, $1.5 \mathrm{ml}$ of supernatant was put into polytetrafluorethylene (PTFE)/ white silicone septa blue cap vials and then analyzed in a gas chromatography device (Thermo 1300, Thermo Fisher Scientific, Waltham, MA, USA) with an automatic sampler (Thermo AI 1310, Thermo Fisher Scientific, Waltham, MA, USA). In the analysis, a column of Fatty Acid Methyl Esters (FAME) (TR-FAME, cat no: P/N 260M154P, Thermo Fisher Scientific, Waltham, MA, USA) (length: $60 \mathrm{~m}$, I.D.: $0.25 \mathrm{~mm}$, film: $0.25 \mu \mathrm{m}$, and maximum temperature of $250 / 260{ }^{\circ} \mathrm{C}$ ) was used. The initial temperature of the column was $100^{\circ} \mathrm{C}$, where it was held for $3 \mathrm{~min}$, and then it was rise to $240{ }^{\circ} \mathrm{C}$ at a rate of $4{ }^{\circ} \mathrm{C} / \mathrm{min}$, and held for $10 \mathrm{~min}$. The device was run at split mode, constant flow, $1 \mathrm{ml} / \mathrm{min}$ flow, $20 \mathrm{ml} / \mathrm{min}$ of split and 1:20 of split ratio. The air was used at flow $350 \mathrm{ml} / \mathrm{min}$ and hydrogen $-35 \mathrm{ml} / \mathrm{min}$. The temperature of flame ionization detector (FID) was $260^{\circ} \mathrm{C}$ (Thermo AI 1310, Thermo Fisher Scientific, Waltham, MA, USA). FAME mix (37C) standard solution (CL.40.13093.0001) in dichloromethane (Chem-Lab, Zedelgem, Belgium) was used for the identification of peak. Helium was used as the carrier gas. Fatty acid identification was performed by comparing and calculating the standard fatty acid peaks in the samples according to retention time using the Xcalibur program (Kramer et al., 1997). Saturated fatty acids (SFA), unsaturated fatty acids (UFA), polyunsaturated fatty acids (PUFA), monounsaturated fatty acids (MUFA), medium-chain fatty acids (MCFA) (fatty acids with chains containing from 6 to 12 atoms of C), long-chain fatty acids (LCFA) (fatty acids with chains containing from 14 to 20 atoms of C) and very long-chain fatty acids (VLCFA) (fatty acids with chains containing above 20 atoms of C) were detected.

\section{Statistical analysis}

The data obtained were evaluated using the SPSS 20.0 statistical package programme (IBM Corp., Armonk, NY, USA). A one-way analysis of variance (ANOVA) was conducted in order to determine whether there was a statistical difference between all parameters and the relevant data, and a Bonferroni multiple comparison test was performed for binary comparisons between groups $(P<0.05)$.

\section{Results}

It was observed that within the growth performance parameters, the initial and final live weights, feed consumption, weight gain, feed conversion ratio, carcass weight and yield were statistically similar in all groups $(P>0.05)$ (Table 2).

The water activity of quail meat was found to be statistically similar in all groups regardless of storage period $(P>0.05)$. Also there was no difference between dietary groups in colour parameters $\left(\mathrm{L}^{*}, \mathrm{a}^{*}, \mathrm{~b}^{*}\right.$ ) on days 1,7 and 11 , and in $\mathrm{pH}$ on days 7 and $11(P>0.05)$. However, a statistical difference was observed between the dietary groups in terms of the $\mathrm{L}^{*}$ (with the highest value in HES2 group), $a^{*}$ (with the lowest value in HES2 group) and $b^{*}$ (with the lowest value in HES1 group) values on day 4 and the $\mathrm{pH}$ parameter on days 1 and $4(P<0.05)$. 
Table 2. Effect of hesperidin addition in different doses to quail diets on growth performance parameters ( $n=100$; mean \pm standard error)

\begin{tabular}{|c|c|c|c|c|}
\hline \multirow{2}{*}{ Indices } & \multicolumn{3}{|l|}{$\operatorname{Diet}^{1}$} & \multirow{2}{*}{$P$-value } \\
\hline & $\bar{C}$ & HES1 & HES2 & \\
\hline Initial body weight, $g$ & $45.39 \pm 3.12$ & $44.14 \pm 0.63$ & $42.95 \pm 2.64$ & 0.40 \\
\hline Final body weight (day 35), g & $223.32 \pm 3.92$ & $222.48 \pm 7.10$ & $225.25 \pm 1.97$ & 0.92 \\
\hline Body weight gain, $g$ & $177.92 \pm 2.83$ & $178.34 \pm 7.17$ & $182.31 \pm 1.33$ & 0.76 \\
\hline Total feed consumption, $\mathrm{g}$ & $565.64 \pm 2.96$ & $559.86 \pm 10.92$ & $569.94 \pm 3.27$ & 0.59 \\
\hline Average feed comsumption, $\mathrm{g}$ & $42.88 \pm 1.89$ & $40.78 \pm 2.64$ & $41.98 \pm 0.79$ & 0.58 \\
\hline Feed conversion ratio, g/g & $3.18 \pm 0.47$ & $3.15 \pm 0.71$ & $3.13 \pm 0.20$ & 0.74 \\
\hline Carcass weight, $g(n=20)$ & $157.18 \pm 3.85$ & $160.32 \pm 4.23$ & $158.21 \pm 3.82$ & 0.85 \\
\hline Carcass yield, $\%(n=20)$ & $70.45 \pm 1.23$ & $74.00 \pm 1.01$ & $70.25 \pm 0.60$ & 0.31 \\
\hline
\end{tabular}

${ }^{1}$ Diets: $\mathrm{C}$ - basal diet, HES1 - basal diet with $1 \mathrm{~g} / \mathrm{kg}$ hesperidin, HES2 - basal diet with $2 \mathrm{~g} / \mathrm{kg}$ hesperidin

On day 1, the $\mathrm{pH}$ was the highest in HES1 group and the lowest in HES2 group, whereas on day 4 the $\mathrm{pH}$ value was the highest in HES1 group and groups HES2 and C did not differ (Table 3).

Lipid peroxidation in meat, measured as TBARS level, was decreased in HES1 and HES2 groups on days 1 and $4(P<0.05)$. No such differences were observed on days 7 and $11(P>0.05)$ (Figure 1).
TMAB (on days 1 and 11), Lactobacillus spp. (on days 1, 7 and 11), Micrococcus/Staphylococcus (on day 4) and TPAB (on day 1 and 4), there was a statistically significant difference between the dietary groups $(P<0.05)$ (Table 4$)$. TMAB was the highest in HES2 group on day 1 and in $\mathrm{C}$ group on day 11. Lactobacillus spp. was the most abundant in meat from HES2 group on day 1 and HES1 group on day 7.

Table 3. The effects of storage time and diet on some meat parameters of quails fed diets supplemented with different doses of hesperidin $(n=12)$

\begin{tabular}{|c|c|c|c|c|c|c|}
\hline \multirow{2}{*}{ Indices } & \multirow{2}{*}{ Diets $^{1}$} & \multicolumn{4}{|c|}{ Storage times, days } & \multirow{2}{*}{$P$-value } \\
\hline & & 1 & 4 & 7 & 11 & \\
\hline \multirow[t]{4}{*}{$\mathrm{pH}$} & C & $6.15 \pm 0.04^{b}$ & $6.27 \pm 0.03^{b}$ & $6.36 \pm 0.12$ & $6.37 \pm 0.03$ & 0.12 \\
\hline & HES1 & $6.26 \pm 0.02^{\mathrm{aB}}$ & $6.66 \pm 0.06^{\mathrm{aA}}$ & $6.29 \pm 0.06^{B}$ & $6.30 \pm 0.06^{B}$ & 0.001 \\
\hline & HES2 & $6.02 \pm 0.04^{\mathrm{CB}}$ & $6.19 \pm 0.05^{\mathrm{bAB}}$ & $6.12 \pm 0.05^{\mathrm{AB}}$ & $6.26 \pm 0.01^{\mathrm{A}}$ & 0.01 \\
\hline & $P$-value & 0.001 & 0.001 & 0.600 & 0.210 & \\
\hline \multirow[t]{4}{*}{$L^{*}$} & C & $44.34 \pm 1.43$ & $43.35 \pm 1.32^{b}$ & $44.10 \pm 0.61$ & $45.73 \pm 0.94$ & 0.53 \\
\hline & HES1 & $44.65 \pm 0.84$ & $39.24 \pm 0.44^{b}$ & $43.41 \pm 2.62$ & $42.39 \pm 2.43$ & 0.25 \\
\hline & HES2 & $45.78 \pm 1.41$ & $51.17 \pm 1.85^{\mathrm{a}}$ & $47.51 \pm 3.28$ & $45.93 \pm 0.62$ & 0.26 \\
\hline & $P$-value & 0.7100 & 0.000 & 0.480 & 0.240 & \\
\hline \multirow[t]{4}{*}{$a^{*}$} & C & $10.87 \pm 0.61$ & $12.07 \pm 0.98^{a}$ & $11.58 \pm 0.25$ & $10.93 \pm 0.76$ & 0.59 \\
\hline & HES1 & $9.37 \pm 0.38^{c}$ & $14.11 \pm 0.70^{\mathrm{aA}}$ & $10.77 \pm 0.79^{\mathrm{BC}}$ & $11.73 \pm 0.88^{B}$ & 0.004 \\
\hline & HES2 & $10.57 \pm 0.66$ & $8.01 \pm 0.69^{b}$ & $9.56 \pm 0.61$ & $10.11 \pm 1.11$ & 0.17 \\
\hline & $P$-value & 0.190 & 0.001 & 0.100 & 0.490 & \\
\hline \multirow[t]{4}{*}{$b^{*}$} & C & $7.99 \pm 1.31$ & $9.12 \pm 0.67^{\mathrm{a}}$ & $8.97 \pm 0.92$ & $7.54 \pm 0.47$ & 0.56 \\
\hline & HES1 & $4.82 \pm 0.70$ & $6.02 \pm 0.80^{\mathrm{b}}$ & $6.37 \pm 0.45$ & $6.27 \pm 0.25$ & 0.27 \\
\hline & HES2 & $7.80 \pm 0.66$ & $9.80 \pm 0.82^{\mathrm{a}}$ & $8.82 \pm 0.83$ & $5.63 \pm 1.52$ & 0.07 \\
\hline & $P$-value & 0.070 & 0.020 & 0.070 & 0.370 & \\
\hline \multirow[t]{4}{*}{$a_{w}$} & C & $0.99 \pm 0.001$ & $0.99 \pm 0.003$ & $0.99 \pm 0.002$ & $0.99 \pm 0.002$ & 0.84 \\
\hline & HES1 & $0.99 \pm 0.004$ & $0.99 \pm 0.002$ & $0.99 \pm 0.002$ & $0.99 \pm 0.001$ & 0.83 \\
\hline & HES2 & $0.99 \pm 0.002$ & $0.99 \pm 0.002$ & $0.99 \pm 0.001$ & $0.99 \pm 0.001$ & 0.40 \\
\hline & $P$-value & 0.870 & 0.390 & 0.280 & 0.820 & \\
\hline
\end{tabular}

${ }^{1}$ Diets: $\mathrm{C}$ - basal diet, HES1 - basal diet with $1 \mathrm{~g} / \mathrm{kg}$ hesperidin, HES 2 - basal diet with $2 \mathrm{~g} / \mathrm{kg}$ hesperidin; $\mathrm{L}^{*}$ - brightness, $\mathrm{a}^{*}$ - redness, $\mathrm{b}^{*}$ - yellowness, $\mathrm{a}_{\mathrm{w}}$ - water activity; ${ }^{\mathrm{a}-\mathrm{c}}-$ means with different superscripts in the same column are significantly different at $P<0.05 ;{ }^{A-C}-$ means with different superscripts in the same row are significantly different at $P<0.05$

In terms of bacterial load in meat, Enterobactericea and Lactococcus spp. counts were statistically similar in the experimental groups in all storage time points $(P>0.05)$. However, in terms of
Micrococcus/Staphylococcus ratio value was the highest in HES2 group on day 4. Whereas TPAB were the most abundant in both hesperidin groups on day 1 and in HES2 group on day 4 . 


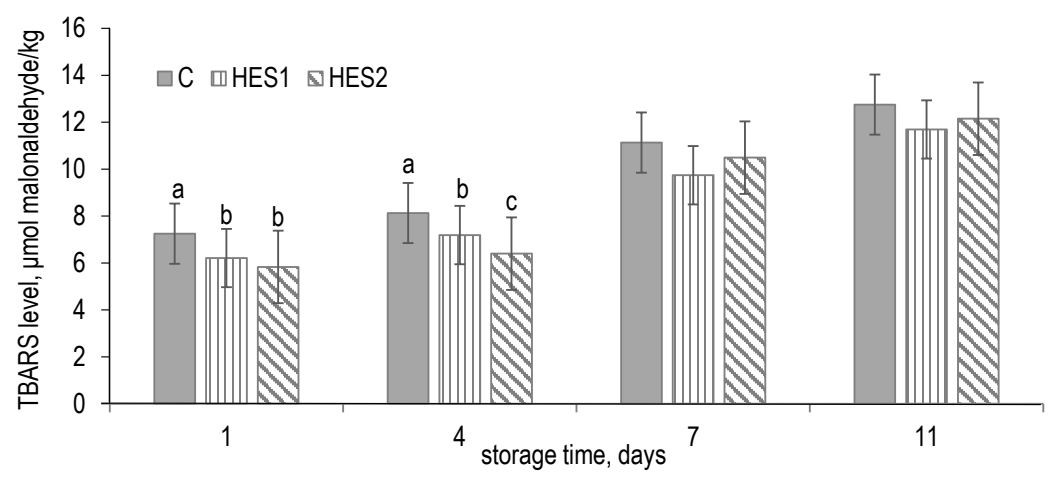

Figure 1. Effect of diet and storage time on TBARS level in meat of quails fed diets supplemented with different doses of hesperidin Diets: C - basal diet, HES1 - basal diet with $1 \mathrm{~g} / \mathrm{kg}$ hesperidin, HES2 - basal diet with $2 \mathrm{~g} / \mathrm{kg}$ hesperidin; TBARS - thiobarbituric acid reactive substances; a-c - bars with different letters within each storage time are significantly different at $P<0.05$

Table 4. Effect of storage time and diet on some bacterial counts in meat of quails fed diets supplemented with different doses of hesperidin $(\log$ CFU/g), $(n=12)$

\begin{tabular}{|c|c|c|c|c|c|c|}
\hline \multirow{2}{*}{ Indices } & \multirow{2}{*}{ Diets $^{1}$} & \multicolumn{4}{|c|}{ Storage times, days } & \multirow{2}{*}{$P$-value } \\
\hline & & 1 & 4 & 7 & 11 & \\
\hline \multirow[t]{4}{*}{ TMAB } & $C$ & $2.99 \pm 0.00^{\mathrm{bD}}$ & $4.63 \pm 0.33^{c}$ & $6.29 \pm 0.21^{B}$ & $7.82 \pm 0.03^{\mathrm{aA}}$ & 0.001 \\
\hline & HES1 & $3.56 \pm 0.15^{\mathrm{bD}}$ & $4.63 \pm 0.35^{c}$ & $6.41 \pm 0.15^{\mathrm{B}}$ & $7.51 \pm 0.10^{\mathrm{bA}}$ & 0.001 \\
\hline & HES2 & $4.52 \pm 0.27^{\mathrm{ac}}$ & $4.38 \pm 0.08^{c}$ & $6.46 \pm 0.05^{\mathrm{B}}$ & $7.43 \pm 0.00^{\mathrm{bA}}$ & 0.001 \\
\hline & $P$-value & 0.020 & 0.790 & 0.730 & 0.040 & \\
\hline \multirow[t]{4}{*}{ Enterobacteriacea } & C & $1.95 \pm 0.00^{B}$ & $1.95 \pm 0.00^{\mathrm{B}}$ & $2.80 \pm 0.10^{\mathrm{A}}$ & $3.15 \pm 0.16^{A}$ & 0.002 \\
\hline & HES1 & $1.85 \pm 0.15^{c}$ & $2.23 \pm 0.00^{B C}$ & $2.52 \pm 0.04^{B}$ & $3.02 \pm 0.17^{A}$ & 0.009 \\
\hline & HES2 & $1.88 \pm 0.10$ & $2.56 \pm 0.29$ & $3.20 \pm 0.50$ & $3.45 \pm 0.25$ & 0.080 \\
\hline & $P$-value & 0.790 & 0.160 & 0.380 & 0.390 & \\
\hline \multirow[t]{4}{*}{ Lactobacillus spp. } & C & $3.10 \pm 0.10^{\circ c}$ & $4.01 \pm 0.12^{B}$ & $4.16 \pm 0.16^{\mathrm{bB}}$ & $4.68 \pm 0.10^{\mathrm{bA}}$ & 0.003 \\
\hline & HES1 & $4.06 \pm 0.02^{\mathrm{bD}}$ & $4.38 \pm 0.03^{c}$ & $4.90 \pm 0.08^{\mathrm{aB}}$ & $5.75 \pm 0.11^{1 \mathrm{~A}}$ & 0.001 \\
\hline & HES2 & $4.67 \pm 0.18^{\mathrm{a}}$ & $4.06 \pm 0.58$ & $4.22 \pm 0.04^{b}$ & $5.16 \pm 0.15^{b}$ & 0.200 \\
\hline & $P$-value & 0.006 & 0.740 & 0.030 & 0.020 & \\
\hline \multirow[t]{4}{*}{ Lactococcus spp. } & C & $2.50 \pm 0.20^{c}$ & $3.57 \pm 0.14^{B}$ & $4.10 \pm 0.06^{A}$ & $4.33 \pm 0.05^{A}$ & 0.002 \\
\hline & HES1 & $3.36 \pm 0.37$ & $4.23 \pm 0.35$ & $4.17 \pm 0.07$ & $4.70 \pm 0.14$ & 0.090 \\
\hline & HES2 & $3.62 \pm 0.32$ & $3.74 \pm 0.12$ & $5.13 \pm 0.37$ & $4.90 \pm 0.70$ & 0.140 \\
\hline & $P$-value & 0.150 & 0.250 & 0.070 & 0.650 & \\
\hline Micrococcus/ & C & $2.95 \pm 0.05^{\mathrm{C}}$ & $3.90 \pm 0.06^{\mathrm{bB}}$ & $4.05 \pm 0.05^{A B}$ & $4.15 \pm 0.00^{A}$ & 0.001 \\
\hline \multirow[t]{3}{*}{ Staphylococcus } & HES1 & $3.71 \pm 0.10^{c}$ & $3.90 \pm 0.01^{\mathrm{bB}}$ & $3.96 \pm 0.04^{B}$ & $4.18 \pm 0.04^{A}$ & 0.001 \\
\hline & HES2 & $3.96 \pm 0.36$ & $4.16 \pm 0.04^{a}$ & $4.78 \pm 0.44$ & $3.74 \pm 0.27$ & 0.250 \\
\hline & $P$-value & 0.090 & 0.030 & 0.190 & 0.230 & \\
\hline \multirow[t]{4}{*}{ TPAB } & C & $1.34 \pm 0.09^{\mathrm{bB}}$ & $2.56 \pm 0.08^{\mathrm{CB}}$ & $5.30 \pm 0.61^{\mathrm{A}}$ & $6.05 \pm 0.16^{A}$ & 0.001 \\
\hline & HES1 & $3.11 \pm 0.17^{\mathrm{ac}}$ & $3.44 \pm 0.02^{b c}$ & $4.66 \pm 0.03^{B}$ & $5.57 \pm 0.06^{A}$ & 0.001 \\
\hline & HES2 & $3.09 \pm 0.48^{\mathrm{aB}}$ & $3.97 \pm 0.09^{\mathrm{aB}}$ & $5.69 \pm 0.03^{A}$ & $6.34 \pm 0.34^{A}$ & 0.005 \\
\hline & $P$-value & 0.040 & 0.002 & 0.260 & 0.180 & \\
\hline
\end{tabular}

${ }^{1}$ Diets: $\mathrm{C}$ - basal diet, HES1 - basal diet with $1 \mathrm{~g} / \mathrm{kg}$ hesperidin, HES2 - basal diet with $2 \mathrm{~g} / \mathrm{kg}$ hesperidin; TMAB - total mesophilic aerobic bacteria count, TPAB - total psychrophilic bacteria count; ${ }^{a-c}-$ means with different superscripts in the same column are significantly different at $P<0.05{ }^{A-D}-$ means with different superscripts in the same row are significantly different at $P<0.05$

A statistically significant difference was found in the fatty acid profile between the experimental groups $(P<0.05)$ (Table 5). The content of $\gamma$-linolenic acid (C18:3n6) was decreased in HES2 group whereas the content of $\alpha$-linolenic acid (C18:3n3), eicosapentaenoic acid (C20:5n3) docosahexaenoic acid (C22:6n3) and the sum of n-3 fatty acids were in this group the highest. Eicosanoic acid
(C20:0) content was the highest in HES2 group but there was no difference between HES2 and HES1 groups; while lignoceric acid (C24:0) content was the greatest in $\mathrm{C}$ group. There was also a difference between dietary groups in terms of the sum of MCFA with the lowest value in HES1 group and the highest in $\mathrm{C}$ group, but with group HES2 not different either from group $\mathrm{C}$ or from group HES1. 
Table 5. Effect of hesperidin addition into diet on fatty acid profile of thigh meat of quail, $g / 100 \mathrm{~g}(\mathrm{n}=8$; mean \pm standard error)

\begin{tabular}{|c|c|c|c|c|}
\hline \multirow{2}{*}{ Indices } & \multicolumn{3}{|l|}{ Diets $^{1}$} & \multirow{2}{*}{$P$-value } \\
\hline & $\mathrm{C}$ & HES1 & HES2 & \\
\hline Capric acid (C10:0) & $0.02 \pm 0.001$ & $0.02 \pm 0.001$ & $0.03 \pm 0.01$ & 0.17 \\
\hline Lauric acid (C12:0) & $0.12 \pm 0.01$ & $0.09 \pm 0.001$ & $0.11 \pm 0.01$ & 0.06 \\
\hline Myristic acid (C14:0) & $0.67 \pm 0.05$ & $0.62 \pm 0.003$ & $0.67 \pm 0.06$ & 0.68 \\
\hline Myristoleic acid (C14:1) & $0.18 \pm 0.02$ & $0.14 \pm 0.01$ & $0.22 \pm 0.04$ & 0.11 \\
\hline Pentadecanoic acid (C15:0) & $0.10 \pm 0.01$ & $0.09 \pm 0.001$ & $0.19 \pm 0.10$ & 0.34 \\
\hline Palmitic acid (C16:0) & $16.99 \pm 0.43$ & $18.84 \pm 0.47$ & $16.29 \pm 1.89$ & 0.29 \\
\hline Palmitoleic acid (C16:1) & $6.51 \pm 0.43$ & $6.92 \pm 0.56$ & $7.12 \pm 1.14$ & 0.85 \\
\hline Heptadecanoic acid (C17:0) & $0.20 \pm 0.02$ & $0.15 \pm 0.01$ & $0.18 \pm 0.05$ & 0.09 \\
\hline Stearic acid $(\mathrm{C} 18: 0)$ & $4.06 \pm 0.23$ & $5.30 \pm 0.25$ & $7.47 \pm 2.47$ & 0.26 \\
\hline Oleic acid (C18:1n9) & $34.76 \pm 1.11$ & $35.87 \pm 0.80$ & $34.20 \pm 1.16$ & 0.52 \\
\hline Linoleic acid (C18:2n6) & $31.52 \pm 0.78$ & $28.44 \pm 0.84$ & $26.69 \pm 3.15$ & 0.23 \\
\hline a-linolenic acid (C18:3n3) & $0.10 \pm 0.02^{b}$ & $0.17 \pm 0.01^{\mathrm{ab}}$ & $1.18 \pm 0.03^{a}$ & 0.001 \\
\hline y-linolenic acid (C18:3n6) & $1.45 \pm 0.08^{\mathrm{a}}$ & $1.33 \pm 0.05^{\mathrm{a}}$ & $0.91 \pm 0.01^{b}$ & 0.01 \\
\hline Eicosanoic acid (C20:0) & $0.05 \pm 0.02^{b}$ & $0.07 \pm 0.01^{\mathrm{ab}}$ & $0.10 \pm 0.01^{a}$ & 0.04 \\
\hline Eicosaenoic acid (C20:1) & $0.01 \pm 0.01^{b}$ & $0.03 \pm 0.01^{\mathrm{a}}$ & $0.03 \pm 0.001^{\mathrm{ab}}$ & 0.03 \\
\hline Arachidonic acid (C20:4n6) & $1.41 \pm 0.29$ & $1.22 \pm 0.24$ & $2.23 \pm 0.35$ & 0.06 \\
\hline Eicosapentaenoic acid (C20:5n3) & $0.06 \pm 0.02^{b}$ & $0.08 \pm 0.02^{b}$ & $0.16 \pm 0.02^{\mathrm{a}}$ & 0.007 \\
\hline Heneicosanoic acid (C21:0) & $0.04 \pm 0.01$ & $0.05 \pm 0.001$ & $0.06 \pm 0.01$ & 0.25 \\
\hline Beheric acid (C22:0) & $0.39 \pm 0.15$ & $0.17 \pm 0.04$ & $0.20 \pm 0.06$ & 0.21 \\
\hline Docosahexaenoic acid (C22:6n3) & $0.28 \pm 0.06^{b}$ & $0.40 \pm 0.09^{b}$ & $0.88 \pm 0.15^{\mathrm{a}}$ & 0.001 \\
\hline Lignoceric acid (C24:0) & $0.78 \pm 0.17^{\mathrm{a}}$ & $0.20 \pm 0.03^{b}$ & $0.09 \pm 0.07^{b}$ & 0.001 \\
\hline$\Sigma S F A$ & $23.12 \pm 0.51$ & $25.48 \pm 0.66$ & $26.04 \pm 1.48$ & 0.11 \\
\hline$\Sigma U F A$ & $76.89 \pm 0.51$ & $74.51 \pm 0.66$ & $73.89 \pm 1.54$ & 0.11 \\
\hline ¿MUFA & $41.60 \pm 1.13$ & $43.03 \pm 0.97$ & $42.60 \pm 1.47$ & 0.69 \\
\hline ¿PUFA & $35.29 \pm 0.96$ & $31.48 \pm 0.87$ & $31.29 \pm 2.64$ & 0.20 \\
\hline$\sum n-3$ & $0.42 \pm 0.06^{\mathrm{b}}$ & $0.66 \pm 0.11^{b}$ & $1.42 \pm 0.11^{\mathrm{a}}$ & 0.001 \\
\hline$\sum n-6$ & $34.47 \pm 0.94$ & $30.65 \pm 0.85$ & $29.38 \pm 3.16$ & 0.19 \\
\hline$\sum n-9$ & $41.51 \pm 1.14$ & $42.97 \pm 0.96$ & $42.17 \pm 1.26$ & 0.66 \\
\hline$n-3 / n-6$ & $0.01 \pm 0.001$ & $0.02 \pm 0.001$ & $0.11 \pm 0.08$ & 0.24 \\
\hline MCFA & $0.16 \pm 0.02^{\mathrm{a}}$ & $0.10 \pm 0.01^{b}$ & $0.15 \pm 0.01^{\mathrm{ab}}$ & 0.02 \\
\hline LCFA & $98.31 \pm 0.24$ & $99.00 \pm 0.08$ & $97.46 \pm 1.21$ & 0.33 \\
\hline VLCFA & $1.54 \pm 0.23$ & $0.89 \pm 0.08$ & $2.33 \pm 1.13$ & 0.33 \\
\hline
\end{tabular}

${ }^{1}$ Diets: C - basal diet, HES1 - basal diet with $1 \mathrm{~g} / \mathrm{kg}$ hesperidin, HES2 - basal diet with $2 \mathrm{~g} / \mathrm{kg}$ hesperidin; $\Sigma$ SFA - total saturated fatty acids,

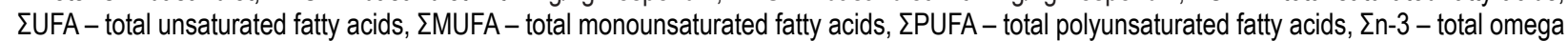
3 fatty acids, $\Sigma n-6$ - total omega 6 fatty acids, $\Sigma n-9$ - total omega 9 fatty acids, n-3/n- 6 - ratio of omega- 3 and omega- 6 fatty acids, MCFA medium-chain fatty acids, LCFA - long-chain fatty acids, VLCFA - very long-chain fatty acids; ${ }^{a-c}-$ means with different superscripts in the same row are significantly different at $P<0.05$

\section{Discussion}

Flavonoids are polyphenolic compounds that, when added to the diet, have many properties that improve the growth performance of farm animals and the quality of the resulting product. Previous studies examined the effects of flavonoids under temperature stress on growth performance in animals (Kamboh and Zhu, 2013). The present study examined the effects of the hesperidin flavonoid addition to quail diets on the birds' growth performance, physical and microbial quality of the carcass and the meat fatty acid profile under normal temperature conditions

Fattening performance. Varying results have been obtained regarding feed consumption, live weight increase and feed conversion ratio after adding flavonoids to animal diets (Kamboh and Zhu, 2013; Goliomytis et al., 2014, 2015). The present study showed no effect of hesperidin on any growth performance or carcass parameter. Previous studies have reported that also citrus pulp (at a dose up to $60 \mathrm{~g} / \mathrm{kg}$ feed) containing naringin $(0.75-1.5 \mathrm{~g} / \mathrm{kg}$ feed), hesperidin $(0.75-3.0 \mathrm{~g} / \mathrm{kg}$ feed), quercetin $(0.5-1 \mathrm{~g} / \mathrm{kg}$ feed) and flavanone did not affect growth performance when added to poultry rations (Simitzis et al., 2011; Hajati et al., 2012; Goliomytis et al., 2014, 2015). It was also observed that Gingko biloba leaves containing high proportions of quercetin glycosides (3.5 and $7 \mathrm{~g} / \mathrm{kg}$ feed) (Cao et al., 2012) and quercetin and citrus $(0.25-1 \mathrm{~g} / \mathrm{kg}$ feed) containing rutin active 
ingredients (Peña et al., 2008) had no effect on live weight gain, feed consumption or FCR in broilers. However, when hesperidin was added to the diet at much lower rates $(0.02 \mathrm{~g} / \mathrm{kg}$ feed $)$, it increased the 42-day live weight of broilers and reduced the FCR value (Kamboh and Zhu, 2013). Moreover, Sohaib et al. (2015) reported that supplementation of quercetin along with $\alpha$-tocopherol $(0.1-0.3 \mathrm{~g} / \mathrm{kg}$ feed) caused an increase in growth performance and a decrease in FCR in broilers. In addition, Ouyang et al. (2016) reported that adding alfalfa extracted flavonoids $(15 \mathrm{mg} / \mathrm{kg}$ feed) to broilers diets had positive effects on daily live weight increase and FCR. The carcass yield for the C, HES1 and HES2 groups were $70.45,74.0$ and $70.23 \%$, respectively. Although there was no significant difference between groups, it is noteworthy that the carcass yield was higher in the group with the low hesperidin dose ( $1 \mathrm{~g} / \mathrm{kg}$ feed). The present study is consistent with the previous studies. Caron et al. (1990) reported that the carcass yield for 45 -day-old quail was $67-70 \%$. The carcass yield of Japanese quails is determined by the type, sex and slaughter age (Genchev et al., 2008). The higher carcass yield of Japanese quails is an indication of their superior productivity and ability to produce meat.

pH and colour parameters. When an animal is alive, the meat $\mathrm{pH}$ is around 7.3, while it drops down to about 7.0 after slaughter and blood extraction. Lactic acid level increases because of a decrease in oxygen level and anaerobic glycolysis in the muscles after slaughter and this leads to a decrease in the $\mathrm{pH}$ value of the meat. The $\mathrm{pH}$ value of meat drops to 5.6-6.2 one hour after slaughter (Savell et al., 2005). High meat acidity is considered as a sign of meat degradation caused by bacteria multiplication. Researchers have reported that $\mathrm{pH}$ value should decrease to 5.7-5.8 post rigor mortis (Savell et al., 2005; Jałosińska and Wilczak, 2009). However, unlike other poultry species (chicken and duck), the pectoral muscle in quails is not entirely glycolytic but consists of dark muscle fibrils that prevent oxidation. This explains the high $\mathrm{pH}$ in quail species compared to broilers. Pectoral muscle is the type of muscle in which post-slaughter rigor mortis occurs more slowly in quails (Drbohlav and Drbohlavova, 1987; Riegel et al., 2003; Genchev et al., 2008). In the present study, the $\mathrm{pH}$ values of the meat on storage days $1,4,7$ and 11 are observed to be between 6.02-6.66. Looking at $\mathrm{pH}$ values, in general, it was observed that the $\mathrm{pH}$ values of meat samples from day 1 to day 11 did not change in HES1 group but increased in control and HES2 group. Similar to the present study, Nasr et al. (2017) found that meat $\mathrm{pH}$ values were between $6.11-6.28$ in quails that consumed the same diet but were classified according to feather colour. Simitzis et al. (2011) observed that the $\mathrm{pH}$ values of the meat at the $24^{\text {th }}$ hour of storgae were between 6.01-6.04 for broilers fed with hesperidin-supplemented ( 1.5 or $3 \mathrm{~g} / \mathrm{kg}$ feed) diets. Leusink et al. (2010) reported that the $\mathrm{pH}$ value of broiler breast meat did not change for broiler, fed diets with different doses of cranberry fruit extract $(0,40,80$ or $160 \mathrm{~g} / \mathrm{kg}$ feed) and were $6.39,6.37$, 6.37 and 6.41, respectively. Genchev et al. (2008) observed that the $\mathrm{pH}$ value of quail meat was 6.17 at the $24^{\text {th }}$ hour of storage and 6.47 on the $7^{\text {th }}$ day. Kim et al. (2020) reported that the $\mathrm{pH}$ value for the broiler meat on days 1, 3, 5, 7 and 9 was initially 5.95, while it was 6.34 on the last day. However, in some studies, lower $\mathrm{pH}$ values than in the present study were reported in meat samples. Goliomytis et al. (2015) reported a similar $\mathrm{pH}$ of 5.40 for the hesperidin, naringin and vitamin E supplemented and nonsupplemented poultry groups at the $24^{\text {th }}$ hour of storage. Peña et al. (2008) reported an average $\mathrm{pH}$ value of 5.40 at the $24^{\text {th }}$ hour for the meat of poultry which consumed diets supplemented with flavonoids, such as ascorbic acid, rutin and quercetin. Simitzis et al. (2014) observed a $\mathrm{pH}$ value of 5.53 at the $24^{\text {th }}$ hour for hares consuming hesperidin-supplemented diets ( 1 and $2 \mathrm{~g} / \mathrm{kg}$ feed). In these previous studies, it was thought that there is a decrease in $\mathrm{pH}$ value due to the use of substances such as ascorbic acid as a supplement to flavonoids.

The colour of the meat is an organoleptic parameter that is judged by consumers when shopping (Fanatico et al., 2007). Brightness ( $\left.\mathrm{L}^{*}\right)$, redness ( $\mathrm{a}^{*}$ ) and yellowness $\left(b^{*}\right)$ values are the basic measured paramters of meat colour despite species (Uğurlu et al., 2017). In the present study, it was determined that the colour parameters in quail meat were affected by the hesperidin addition but only on day 7 of storage. At this time point, the higher dose of hesperidin increased brightness with a simultaneous decrease in redness; whereas yellowness was lower in the group fed with a lower dose of hesperidin. The average values of meat colour parameters in the present study were 44.8, 10.8 and 7.43 , respectively for $L^{*}, a^{*}$ and $b^{*}$. Nasr et al. (2017) reported that meat colour values of $\mathrm{L}^{*}(44.23-46.40)$, $a^{*}(9.20-9.31)$ and $b^{*}(12.10-12.46)$ were dependent on feather colours (white, yellow, black, brown) in quails fed the same diet. However, a review of the literature shows a large discrepancy in the results concerning the colour of poultry meat. 
In comparison to the present study, Goliomytis et al. (2015) found a more pronounced effect of hesperidin at lower doses $(0.75-1 \mathrm{~g} / \mathrm{kg})$ on the $\mathrm{L}^{*}$, a* and $b^{*}$ values for the breast meat of broilers. Simitzis et al. (2014) reported that hesperidin (1-2 g/ $\mathrm{kg}$ ) influenced to a greater extent $\mathrm{L}^{*}$ and $\mathrm{b}^{*}$ values and to a lesser extend $\mathrm{a}^{*}$ value of breast meat of hares than in the present study. Similarly, Riegel et al. (2004) obtained $\mathrm{L}^{*}, \mathrm{a}^{*}$ and $\mathrm{b}^{*}$ values of $40.0,10.9$ and 2.5, respectively, for turkey pectoral muscle $20 \mathrm{~min}$ after slaughter. In terms of $\mathrm{L}^{*}, \mathrm{a}^{*}$ and $\mathrm{b}^{*}$ values in quail meat, Genchev et al. (2008) reported values of $40.81-45.67,10.16-11.68$ and $9.55-14.48$ on days 1 and 7, respectively, which were rather similar to values obtained in the present study.

Lipid peroxidation. The most expected effect of flavonoids addition into diets is its influence on lipid oxidation in meat. In the literature, flavonoid supplementation is reported to reduce MDA concentration (lipid peroxidation indicator) depending on storage time (Simitzis et al., 2011; Goliomytis et al., 2014). In the present study, the concentrations of MDA in thigh tissue of quails were lower in hesperidin supplemented groups on days 1 and 4 of storage. Previous studies demonstrated a lower concentration of MDA in breast meat compared to thigh meat (Goliomytis et al. 2014; Sohaib et al. 2015); however in the present study only the thight meat was examined and it can be only stated that as a result of prolonged storage time (up to 11 days) MDA concentration increased with hesperidin effect in the first days of storage. Similar to the present study, the previous studies have presented a decrease in the lipid peroxidation due to supplementation of flavonoids (or extracts/ pulps containing them) such as quercetin (0.5-1 g/kg (Goliomytis et al., 2014) and $0.1-0.3 \mathrm{~g} / \mathrm{kg}$ (Sohaib et al., 2015)), naringin (0.75-1.5 g/kg; Goliomytis et al. (2015)), hesperidin (1.5-3 g/ kg; Simitzis et al. (2011)), genistein and hesperidin (0.005 and $0.02 \mathrm{~g} / \mathrm{kg}$, respectively; Kamboh and Zhu (2013)), isoflavones (0.01-0.08 g/ kg; Jiang et al. (2007)), tea catechins (0.05-0.3 g/kg; Tang et al. (2001)), grape pulp (5-30 g/kg; Goñi et al. (2007); 15-60 g/kg; Brenes et al. (2008)) or Ginkgo biloba leaves (3.5 and $7 \mathrm{~g} / \mathrm{kg}$; Cao et al. (2012)).

Microbial load. One of the factors affecting meat quality is the microbial load of meat. Some microorganisms found in meat disrupt the quality of the meat, shorten its shelf life and pose a risk to human health. In such a context, this study examined the relationship between total mesophilic aerobic bacteria (TMAB), total psychrophilic aerobic bacteria (TPAB), Enterobacteriaceae, Lactobacillus spp., Lactococcus spp. and Micrococcus/Staphylococcus concentrations and storage time. Insausti et al. (2001) reported that 6-8 $\log \mathrm{CFU} / \mathrm{g}$ is an acceptable microbial limit for the total number of bacteria in meat. Karay1lirim (2017) reported that hesperidin, when administered in vitro, has antibacterial activity on Gram-positive (Lactobacillus) and Gramnegative (Enterobacteriaceae) bacteria. The present study showed an increase for all bacterial species on day 11 of storage but any bacterial species exceeded $8 \log \mathrm{CFU} / \mathrm{g}$. Previous studies reported results supporting the present study (Insausti, 2001; Nieto et al., 2012). Ambrosio et al. (2020) reported that citrus terpenes, when administered in vitro, had more antibacterial activity on Escherichia coli (Gram-negative) than on Lactobacillus rhamnosus (Gram-positive). In the present study, Enterobacteriaceae was stated as bacteria family with the lowest concentration at day 11 . In the study supporting such a result, Nieto et al. (2012) were unable to detect Enterobacteriaceae bacteria, when they added thyme to lamb rations at varying rates. However, in terms of total bacteria, psychrophilic and lactic acid bacteria, the results of that experiment on day 11 were similar to the present study. Also, Kamboh et al. (2018) reported that storing meat from poultry fed diets with genistein and hesperidin addition in the refrigerator reduced microbial load of bacteria increasing degradation parameters of meat and increased the total amount of psychrophilic and lactic acid bacteria after 15 days of storage. In the present study, psychrophilic bacteria concentration increased upon storage time both in the control and experimental groups. Moreover, it was observed that hesperidin addition into quails diet increased psychrophilic bacteria concentration on days 1 and 4 . However, especially the HES1 group ( $\mathrm{pH}$ 6.30) among the hesperidin-supplemented groups was observed to be more balanced than the $\mathrm{C}$ group, despite having a higher $\mathrm{pH}$ than the $\mathrm{C}$ group ( $\mathrm{pH}$ 6.40). In the same manner, as the previous studies, it is thought that a lower degradation occurs due to hesperidin supplementation compared to storage time.

Fatty acid profile. Saturated fatty acids (SFA), especially stearic, lignoceric, palmitic and myristic acids, are generally considered harmful to health due to their hypercholesterolemic properties (FAO/WHO, 2008). In the present study, hesperidin addition into quail diet did not influence the sum of SFA as well as contents of the most common SFA such as lauric (C12:0), myristic (C14:0), palmitic (C16:0) and stearic (C18:0) acids. However, 
eicosanoic acid (C20:0) content was the highest in HES2 group but there was no difference between HES2 and HES1 groups; while lignoceric acid $(\mathrm{C} 24: 0)$ content was the greatest in the control group. The results of the present study match those of Genchev et al. (2008) and Simitzis et al. (2014) regarding the composition of fatty acids in meat. However, it does not match those of many previous studies. Quercetin supplementation in lamb caused a decrease in SFA ratio (Andrés et al., 2014), as well as fermented Ginkgo biloba leaves containing flavonoids addition into broilers feed (Cao et al., 2012). Kamboh and Zhu (2013) reported a decrease in SFA upon supplementation of bioflavonoids in the ration, and an increase in the polyunsaturated fatty acid (PUFA) concentration. Besides PUFA content in meat was reported to be influenced by direct PUFA addition in the chicken diet (Cortinas et al., 2004). PUFA can be divided into n-3 (e.g., $\alpha$-linolenic acid (C18:3), eicosapentaenoic acid (C20:5), docosahexaenoic acid (C22:6)) and n-6 (e.g., linoleic acid (C18:2), $\gamma$-linolenic acid (C18:3) and arachidonic acid (C20:4)). In the human diet, n-3 and n-6 fatty acids have been reported to play an important role in the immune system due to being precursors to eicosanoids, prostaglandins, leukotrienes and thromboxanes (Grashorn, 2007); however, proportion n- 6 to $n-3$ seems to be crucial as an excess of n-6 may exert a pro-inflammatory effect. In addition, it was reported that an increase in the concentration of n-3 fatty acid would lead to a decrease in the concentration of $n-6$ fatty acid, which is associated with a competition for the use of the same enzymes in the desaturation metabolism $(\mathrm{Nu}-$ ernberg et al., 2005). In the present study, the content of $\gamma$-linolenic acid (C18:3n6) was decreased in the group supplemented with a higher dose of hesperidin (HES2), whereas the content of $\alpha$-linolenic acid (C18:3n3), eicosapentaenoic acid (C20:5n3), docosahexaenoic acid (C22:6n3) and the sum of n-3 fatty acids were in this group the highest. Such results suggest that hesperidin addition increases n-3 fatty acids exerting a health-promoting effect. Similarly, Kamboh and Zhu (2013) reported dietary bioflavonoids genistein and hesperidin could positively improve the fatty acid and lipid metabolite profile (increase proportion of total PUFA and decrease the ratio of $n-6$ to $n-3$ fatty acids) of broiler breast meat in a dose-dependent fashion. On the other hand, Jenkins and Atwal (1995) stated that quercetin, morin and ferulic acid had marked effects on the fatty acid composition of tissue lipids in chickens, reducing oleic acid $(\mathrm{C} 18: 1)$ and $\mathrm{C} 20: 3 \mathrm{n} 9$ and increasing linoleic acid (C18:2), arachidonic acid
(C20:4)) and total n-6 fatty acids. In the present study, no effect of hesperidin on monounsaturated fatty acids (MUFA) such as oleic and palmitoleic acid concentrations was stated.

\section{Conclusions}

Hesperidin added to quail diets in varying doses (1 and $2 \mathrm{~g} / \mathrm{kg}$ ) had a limited effect on the growth performance parameters, such as live weight, feed consumption and feed conversion ratio. Nevertheless, it was determined that the hesperidin addition had an antibacterial effect on quail thigh meat and a positive impact on lipid peroxidation and fatty acid profile of meat. So, it can be concluded that the hesperidin addition to quail diets may both influence shelf life quality of quail meat and exert a health-promoting effect increasing $n-3$ polyunsaturated fatty acids content, which can increase consumer interest in quail meat.

\section{Conflict of interest}

The authors declare that there is no conflict of interest.

\section{References}

Ambrosio C.M.S., Contreras-Castillo C.J., Da Gloria E.M., 2020. In vitro mechanism of antibacterial action of a citrus essential oil on an enterotoxigenic Escherichia coli and Lactobacillus rhamnosus. J. Appl. Microbiol. 129, 541-553, https://doi. org/10.1111/jam. 14660

Andrés S., Morán L., Aldai N., Tejido M.L., Prieto N., Bodas R., Giráldez F.J., 2014. Effects of linseed and quercetin added to the diet of fattening lambs on the fatty acid profile and lipid antioxidant status of meat samples. Meat Sci. 97, 156-163, https://doi.org/10.1016/j.meatsci.2014.02.001

AOAC International, 2000. Official Methods of Analysis of AOAC International. $17^{\text {th }}$ Edition. Gaithersburg, MD (USA)

Baumgart J., Becker B., Stephan S., 2015. Microbiological Examination of Food: A Guide to Study (in German: Mikrobiologische Untersuchung von Lebensmitteln: Ein Leitfaden für das Studium). Behr's Verlag. Hamburg (Germany)

Brenes A., Viveros A., Goñi I., Centeno C., Saura-Calixto F., Arija I., 2010. Effect of grape seed extract on growth performance, protein and polyphenol digestibilities, and antioxidant activity in chickens. Span. J. Agric. Res. 8, 326-333, https://doi. org/10.5424/sjar/2010082-1199

Cao F.L., Zhang X.H., Yu W.W., Zhao L.G., Wang T., 2012. Effect of feeding fermented Ginkgo biloba leaves on growth performance, meat quality, and lipid metabolism in broilers. Poult. Sci. 91, 1210-1221, https://doi.org/10.3382/ps.2011-01886

Caron N., Minvielle F., Desmarais M., Poste L.M., 1990. Mass selection for 45-day body weight in Japanese quail: selection response, carcass composition, cooking properties, and sensory characteristics. Poult Sci. 69, 1037-1045, https://doi. org/10.3382/ps.0691037 
Cortinas L., Villaverde C., Galobart J., Baucells M.D., Codony R., Barroeta A.C., 2004. Fatty acid content in chicken thigh and breast as affected by dietary polyunsaturation level. Poult. Sci. 83, 1155-1164, https://doi.org/10.1093/ps/83.7.1155

Drbohlav V., Drbohlavova D., 1987. The effect of storage on some properties characterizing the quality of broiler meat. Food Ind. Sci. III, 1, 25-29

Engberg R.M., Lauridsen C., Jensen S.K., Jakobsen K., 1996. Inclusion of oxidized vegetable oil in broiler diets. Its influence on nutrient balance and on the antioxidative status of broilers. Poult. Sci. 75, 1003-1011, https://doi.org/10.3382/ ps. 0751003

Erlund I., 2004. Review of the flavonoids quercetin, hesperetin, and naringenin. Dietary sources, bioactivities, bioavailability, and epidemiology. Nutr. Res. 24, 851-874, https://doi. org/10.1016/j.nutres.2004.07.005

Fanatico A.C., Pillai P.B., Emmert J.L., Gbur E.E., Meullenet J.F. Owens C.M., 2007. Sensory attributes of slow-and fastgrowing chicken genotypes raised indoors or with outdoor access. Poult. Sci. 86, 2441-2449, https://doi.org/10.3382/ ps.2007-00092

FAO/WHO, 2008. Fats and fatty acids in human nutrition. Proceedings of the Joint FAO/WHO Expert Consultation. November 10-14. Geneva (Switzerland)

Garg A., Garg S., Zaneveld L.J.D., Singla A.K., 2001. Chemistry and pharmacology of the citrus bioflavonoid hesperidin. Phytother. Res. 15, 655-669, https://doi.org/10.1002/ptr.1074

Genchev A., Mihaylova G., Ribarski S., Pavlov A., Kabakchiev M., 2008. Meat quality and composition in Japanese quails. Trakia J. Sci. 6(4), 72-82, http://www.uni-sz.bg/tsj/TJS-Vol.6\%20 N4\%202008/Genchev_kachestvoEn.pdf

Gökalp H.Y., Kaya M., Tülek Y., Zorba O., 2001. Guide for quality control and laboratory application of meat products. Atatürk Univ. Publ. No. 751. Atatürk University. Erzurum (Turkey)

Goliomytis M., Kartsonas N., Charismiadou M.A., Symeon G.K., Simitzis P.E., Deligeorgis S.G., 2015. The influence of naringin and hesperidin dietary supplementation on broiler meat quality and oxidative stability. PLOS ONE 10, e0141652, https://doi.org/10.1371/journal.pone.0141652

Goliomytis M., Tsoureki D., Simitzis P.E., Charismiadou M.A., HagerTheodorides A.L., Deligeorgis S.G., 2014. The effects of quercetin dietary supplementation on broiler growth performance, meat quality, and oxidative stability. Poult. Sci. 93, 1957-1962, https://doi.org/10.3382/ps.2013-03585

Goñi I., Brenes A., Centeno C., Viveros A., Saura-Calixto F., Rebolé A., Arija I., Estevez R., 2007. Effect of dietary grape pomace and vitamin $\mathrm{E}$ on growth performance, nutrient digestibility, and susceptibility to meat lipid oxidation in chickens. Poult. Sci. 86, 508-516, https://doi.org/10.1093/ps/86.3.508

Grashorn M.A., 2007. Functionality of poultry meat. J. Appl. Poult. Res. 16, 99-106, https://doi.org/10.1093/japr/16.1.99

Hajati H., Hassanabadi A., Yansari A.T., 2012. Effect of citrus pulp on performance and some blood parameters of broiler chickens. In: Proceedings of the $1^{\text {st }}$ International and the $4^{\text {th }}$ National Congress on Recycling of Organic Waste in Agriculture. 2012, Isfahan (Iran), http://conference.khuisf.ac.ir/DorsaPax/ userfiles/file/pazhohesh/crowa91/45.pdf

Insausti K., Beriain M.J., Purroy A., Alberti P., Gorraiz C., Alzueta M.J., 2001. Shelf life of beef from local Spanish cattle breeds stored under modified atmosphere. Meat Sci. 57, 273-281, https://doi.org/10.1016/S0309-1740(00)00102-9

Jałosińska M., Wilczak J., 2009. Influence of plant extracts on the microbiological shelf life of meat products. Pol. J. Food Nutr. Sci. 59, 303-308, http://journal.pan.olsztyn.pl/pdf-9822230938?filename=INFLUENCE\%200F\%20PLANT.pdf
Jenkins K.J., Atwal A.S., 1995. Flavonoids increase tissue essential fatty acids in vitamin E-deficient chicks. J. Nutr. Biochem. 6 , 97-103, https://doi.org/10.1016/0955-2863(94)00018-H

Jiang Z.Y., Jiang S.Q., Lin Y.C., Xi P.B., Yu D.Q., Wu T.X., 2007. Effects of soybean isoflavone on growth performance, meat quality, and antioxidation in male broilers. Poult. Sci. 86, 1356-1362, https://doi.org/10.1093/ps/86.7.1356

Kamboh A.A., Zhu W.Y., 2013. Effect of increasing levels of bioflavonoids in broiler feed on plasma anti-oxidative potential, lipid metabolites, and fatty acid composition of meat. Poult. Sci. 92, 454-461, https://doi.org/10.3382/ps.2012-02584

Kamboh A.A., Memon A.M., Mughal M.J., Memon J., Bakhetgul M., 2018. Dietary effects of soy and citrus flavonoid on antioxidation and microbial quality of meat in broilers. J. Anim. Physiol. Anim. Nutr. 102, 235-240, https://doi.org/10.1111/jpn.12683

Kara K., Guclu B.K., Senturk M., Eren M., Baytok E., 2021. Effects of catechin and copper or their combination in diet on productive performance, egg quality, egg shelf-life, plasma 8-OHdG concentrations and oxidative status in laying quail (Coturnix coturnix japonica). J. Appl. Anim. Res. 49, 97-103, https://doi. org/10.1080/09712119.2021.1891074

Kara K., Güçlü B.K., Baytok E., Şentürk M., 2016c. Effects of grape pomace supplementation to laying hen diet on performance, egg quality, egg lipid peroxidation and some biochemical parameters. J. Appl. Anim. Res. 44, 303-310, https://doi.org/10. 1080/09712119.2015.1031785

Kara K., Güçlü B.K., Şentürk M., Konca Y., 2016a. Influence of catechin (flavan-3-ol) addition to breeder quail (Coturnix coturnix japonica) diets on productivity, reproductive performance, egg quality and yolk oxidative stability. J. Appl. Anim. Res. 44, 436-441, https://doi.org/10.1080/09712119.2015.1091337

Kara K., Şentürk M., Guclu B.K., Sariözkan S., Eren M., 2016b. Effect of catechins on fattening performance, meat quality, some antioxidant and blood parameters and fattening costs in Japanese quail (Coturnix coturnix japonica). Br. Poult. Sci. 57, 522-530, https://doi.org/10.1080/00071668.2016.1174977

Karayıldırım Ç.K., 2017. Characterization and in vitro evolution of antibacterial efficacy of novel hesperidin microemulsion. Celal Bayar Üniv. J. Sci. 13, 943-947, https://doi.org/10.18466/ cbayarfbe. 370370

Kim H.J., Kim H.J., Jeon J., Nam K.C., Shim K.S., Jung J.H., Kim K.S., Choi Y., Kim S.H., Jang A., 2020. Comparison of the quality characteristics of chicken breast meat from conventional and animal welfare farms under refrigerated storage. Poult. Sci. 99, 1788-1796, https://doi.org/10.1016/j.psj.2019.12.009

Kramer J.K.G., Fellner V., Dugan M.E.R., Sauer F.D., Mossoba M.M., Yurawecz M.P., 1997. Evaluating acid and base catalysts in the methylation of milk and rumen fatty acids with special emphasis on conjugated dienes and total trans fatty acids. Lipids 32, 1219-1228, https://doi.org/10.1007/s11745-997-0156-3

Leusink G., Rempel H., Skura B. et al., 2010. Growth performance, meat quality, and gut microflora of broiler chickens fed with cranberry extract. Poult. Sci. 89, 1514-1523, https://doi. org/10.3382/ps.2009-00364

Maraschiello C., Esteve E., Garcia-Regueiro J.A., 1998. Cholesterol oxidation in meat from chickens fed a-tocopherol and $\beta$-carotene supplemented diets with different unsaturation grades. Lipids 33, 705-710, https://doi.org/10.1007/s11745998-0260-4

Nasr M.A.F., Ali E.M.R., Hussein M.A., 2017. Performance, carcass traits, meat quality and amino acid profile of different Japanese quails strains. J. Food Sci. Technol. 54, 4189-4196, https://doi.org/10.1007/s13197-017-2881-4 
Nieto G., Bañón S., Garrido M.D., 2012. Administration of distillate thyme leaves into the diet of Segureña ewes: effect on lamb meat quality. Animal 6, 2048-2056, https://doi.org/10.1017/ S1751731112001012

NRC (National Research Council), 1994. Nutrient Requirements of Poultry. $9^{\text {th }}$ Revised Edition. The National Academies Press. Washington, DC (USA), https://doi.org/10.17226/2114

Nuernberg K., Fischer K., Nuernberg G., Kuechenmeister U., Klosowska D., Eliminowska-Wenda G., Fiedler I., Ender K., 2005. Effects of dietary olive and linseed oil on lipid composition, meat quality, sensory characteristics and muscle structure in pigs. Meat Sci. 70, 63-74, https://doi.org/10.1016/j.meatsci.2004.12.001

Ouyang K., Xu M., Jiang Y., Wang W., 2016. Effects of alfalfa flavonoids on broiler performance, meat quality, and gene expression. Can. J. Anim. Sci. 96, 332-341, https://doi.org/10.1139/cjas2015-0132

Peña J.E.M., Vieira S.L., López J., Reis R.N., Barros R., Furtado F.V.F., Silva P.X., 2008. Ascorbic acid and citric flavonoids for broilers under heat stress: effects on performance and meat quality. Braz. J. Poult. Sci. 10, 125-130, https://doi.org/10.1590/ S1516-635X2008000200008

Riegel J., Rosner F., Schmidt R., Schuler L., Wicke M., 2003. Investigation of meat quality of $m$. Pectoralis in male and female japanese quails (Coturnix japonica). In: Proceeding of the XV|th European Symposium on the Quality of Poultry Meat. 2003, Saint-Brieuc (France)

Riegel J., Maak S., Behr K.P., Wicke M., 2004. Investigations on meat quality of the Pectoralis superficialis in turkey depending on line and age. In: Proceeding of the XXII World's Poultry Congress. 2004, Istanbul (Turkey)

Robbins R.J., 2003. Phenolic acids in foods: an overview of analytical methodology. J. Agric. Food. Chem. 51, 2866-2887, https://doi. org/10.1021/jf026182t

Sárraga C., García Regueiro J.A., 1999. Membrane lipid oxidation and proteolytic activity in thigh muscles from broilers fed different diets. Meat Sci. 52, 213-219, https://doi.org/10.1016/S03091740(98)00170-3
Savell J.W., Mueller S.L., Baird B.E., 2005. The chilling of carcasses. Meat Sci. 70, 449-459, https://doi.org/10.1016/j.meatsci.2004.06.027

Simitzis P.E., Babaliaris C., Charismiadou M.A., Papadomichelakis G., Goliomytis M., Symeon G.K., Deligeorgis S.G., 2014. Effect of hesperidin dietary supplementation on growth performance, carcass traits and meat quality of rabbits. World Rabbit Sci. 22, 113-121, https://doi.org/10.4995/wrs.2014.1760

Simitzis P.E., Symeon G.K., Charismiadou M.A., Ayoutanti A.G., Deligeorgis S.G., 2011. The effects of dietary hesperidin supplementation on broiler performance and chicken meat characteristics. Can. J. Anim. Sci. 91, 275-282, https://doi. org/10.4141/cjas 10094

Simopoulos A.P., 2000. Human requirement for $n-3$ polyunsaturated fatty acids. Poult. Sci. 79, 961-970, https://doi.org/10.1093/ ps/79.7.961

Smet K., Raes K., Huyghebaert G., Haak L., Arnouts S., De Smet S., 2008. Lipid and protein oxidation of broiler meat as influenced by dietary natural antioxidant supplementation. Poult. Sci. 87, 1682-1688, https://doi.org/10.3382/ps.2007-00384

Sohaib M., Butt M.S., Shabbir M.A., Shahid M., 2015. Lipid stability, antioxidant potential and fatty acid composition of broilers breast meat as influenced by quercetin in combination with a-tocopherol enriched diets. Lipids Health Dis. 14, 61, https:// doi.org/10.1186/s12944-015-0058-6

Tang S.Z., Kerry J.P., Sheehan D., Buckley D.J., Morrissey P.A., 2001. Antioxidative effect of dietary tea catechins on lipid oxidation of long-term frozen stored chicken meat. Meat Sci. 57, 331-336, https://doi.org/10.1016/S0309-1740(00)00112-1

Uğurlu M., Ekiz B., Teke B., Salman M., Akdağ F., Kaya I., 2017. Meat quality traits of male Herik lambs raised under an intensive fattening system. Turk. J. Vet. Anim. Sci. 41, 425-430, https:// doi.org/10.3906/vet-1701-79

Wang J., Wu W., Wang X., Wang M., Wu F., 2015. An affective GC method for the determination of the fatty acid composition in silkworm pupae oil using a two-step methylation process. J. Serb. Chem. Soc. 80, 9-20, https://doi.org/10.2298/ JSC140401073W 